\title{
Sustainable Watersheds: Assessing the Source and Load of Cisadane River Pollution
}

\author{
Adipati Rahmat Gumelar, Abimanyu Takdir Alamsyah, Ida Bagus Hendra Gupta, Darul Syahdanul, and \\ Daniel Mambo Tampi
}

\begin{abstract}
Cisadane watersheds is a very valuable strategic area for the people in Tangerang District, Banten, Indonesia. But that strategic value has brings an impact in the form of water pollution, that comes from its popullation and economic activities. This water pollution load is necessary to know its source, and also how much, so that public, private and local governments can jointly take action to restore the water quality of the Cidasane River. The purpose of this study is to determine the pollution load in the Cidasane watersheds. The study will taking sample of Cisadane River water as an inputs in the isoyet map pollution dispersion modeling. And calculating the load in the river using QUAL2Kw modelling. The results of the modeling are then analyzed to obtain the amount of Cisadane River pollutant load. The pollution load in this study will be focused on BOD, NO3, and Total P, and Salinity. This research has shown the inter-regional pollution spread on the Cisadane river, which used This study will provide a measurable data of the type and scale of the pollution load in Cisadane, as an input for Cisadane River water quality restoration policy making by the Government of Tangerang.
\end{abstract}

Index Terms-Cisadane river, Isoyet map, pollution load, QUAL2Kw model, sustainable watersheds.

\section{INTRODUCTION}

Nature constantly changes, however human have not always adapted to such changes. Even when such changes have been triggered by the human themselves. River is one of the form of nature environment which in this case has undergone rapid changes.

Cisadane River is one of the major rivers in Java Island which flows $114 \mathrm{~km}$ passing several regencies and municipalities specifically Bogor Regency, Bogor Municipality, Tangerang Regency, South Tangerang Municipality, and Tangerang Municipality and ultimately enters the Java Sea. Cisadane River Watershed is the home of approximately 1.7 millions people. It serves as the source of clean water for agriculture, animal husbandry, industries, and raw water supply for PDAM (regional water utility company). However, due to years of pollution, water quality of Cisadane River today has been declared as severely polluted [1].

The purpose of this study is to comprehend the pollution of Cisadane River in conjunction with the efforts to prepare pollution mitigation strategies based on the principle of

Manuscript received October 30, 2016; revised December 30, 2016.

The authors are with the Universitas Indonesia, Jakarta, Indonesia (e-mail: adipatirahmat@gmail.com, takdir65@gmail.com, hendragupta@gmail.com, darul.syahdanul@gmail.com,danielmambo131293@gmail.com). sustainability along Cisadane Watershed.

\section{Methods}

Cisadane River is one of the major rivers in Java Island in which the lower end meets the tidal at the northern coast of Java Island. The upstream region of the Cisadane River is situated at the slope of Mount Pangrango with a number of tributaries which are originated in Mount Salak. Geographically, Cisadana Watershed is situated between $6^{\circ} 02^{\prime} \mathrm{S}$ to $6^{\circ} 54^{\prime} \mathrm{S}$ and $106^{\circ} 17^{\prime} \mathrm{E}$ [2].

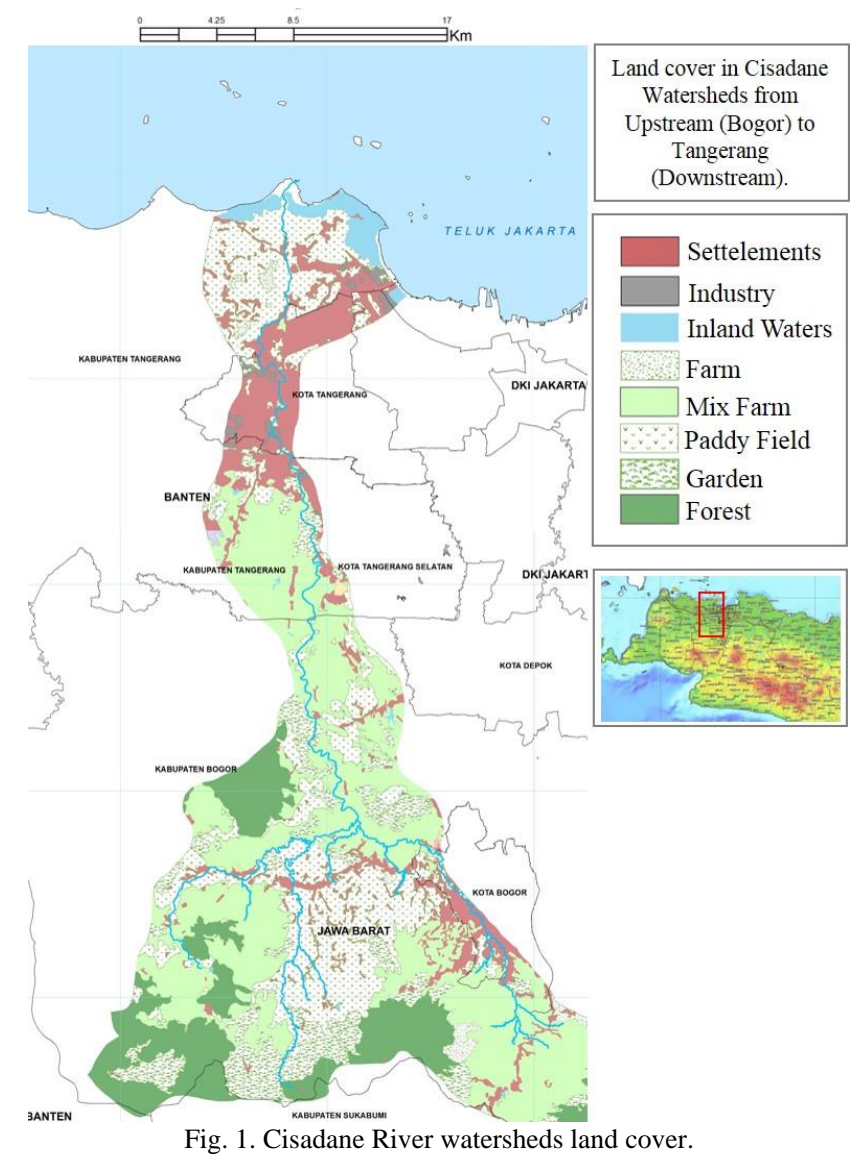

Cisadane Watershed is bordered by Cimanceuri Sub-Watershed in the West and Ciliwung Watershed in the East, as seen in Fig. 1. Altogether Cisadane river system is made up of 10 tributaries specifically Cisindangbarang, Ciapus, Cihideung, Cinangneng, Ciampea, Ciaruteun, Cikaniki, Citempuan, and Cisuuk.

The purpose of this research is to determine the magnitude of the pollution load as well as the types of element of pollutants' load which contaminate Cisadane River, for furtther formulation with respect to the mitigation strategies. 
Modelling of land pollution load transported to the Cisadane River will rely on QUAL2Kw method. QUAL2Kw is a simulation framework of water quality in the river by applying the approach of single dimension flow type through steady pattern [3].

Primary data for QUAL2Kw method will be acquired through field survey in the estuary of Cisadane River. Such data will be used as an input to the isohyet map modelling on the pollution distribution in Cisadane River as well as load calculation modelling in the river using QUAL2Kw application. The result of such modelling will then be analyzed to determine the extent of pollutant load in Cisadane River. Pollutant load assessed on this research will be focused on BOD, $\mathrm{NO}_{3}$, and Total P elements.

Literature study with respect to the continuity of the Watershed management is undertaken to enhance the knowledge on the research results along with the follow-up actions or strategies which must be implemented to improve water quality along the Cisadane River.

\section{DISCUSSION AND ANALYSIS}

Prior to inputting the data on QUAL2Kw program, the first step which need to be performed is dividing the river into different sections in which calculation on the pollutant load of each section will be carried out. Division into several sections is carried out in consideration of different physical characteristics of the river (depth and width) as well as presence of point sources entering the river. In a QUAL2Kw modelling, the designation of $0 \mathrm{~km}$ point is at the very end of the downstream region. On this current research, the outset of the river starts at the downstream region situated in Muara Jaya Village (Bogor Regency) down to Teluk Naga Subdistrict (Tangerang Regency).

\section{A. Cisadane River Water Quality}

On a pollutant load modelling, all data of pollutant load were input into the QUAL2Kw application to acquire the accumulation of pollutant load on each segment of the river. Source of pollutants consist of domestic and industrial wastes. Calculation of industrial waste is based on discharge data and quality of industrial wastes which discharge their effluent wastes to Cisadane River.

In addition to the simulation of pollutant load, data of water usage along the Cisadane River have also been input. The use of this water will reduce river water discharge and thus affect the amount of pollutant concentration in the river.

Parameters of water quality testd include among other BOD, NO3, and Total P.

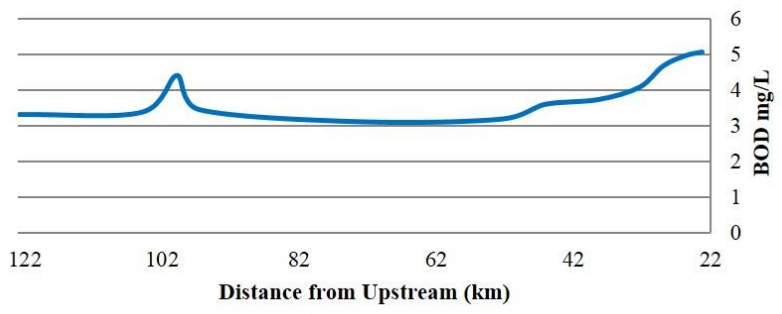

Fig. 2. Quality of BOD in Cisadane river.

In Fig. 2 above, it is snown that the BOD quality at all monitoring points do not meet the Second Class Benchmark which should be below $3 \mathrm{mg} / \mathrm{L}$, but the value of BOD reach 5 $\mathrm{mg} / \mathrm{L}$ about $22 \mathrm{~km}$ from upstream (around Bogor Municipality). It also recorded to reach 4,5 mg/L about 102 $\mathrm{km}$ from upstream (in Tangerang Municipality). Such values fluctuate and the greatest BOD value is identified at the downstream part of the Cisadane River.

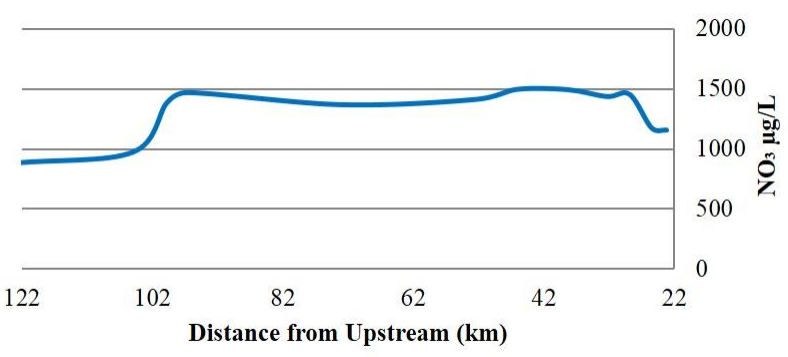

Fig. 3. Quality of $\mathrm{NO}_{3}$ in Cisadane river.

The Fig. 3 above illustrates that the values of NO3 at all points of observation remain within the Second Class Benchmark (below 10,000 $\mu \mathrm{g} / \mathrm{L}$ ). The NO3 value has been identified to increase after passing $\mathrm{km} 102$ point and decreases at the dowstream region.

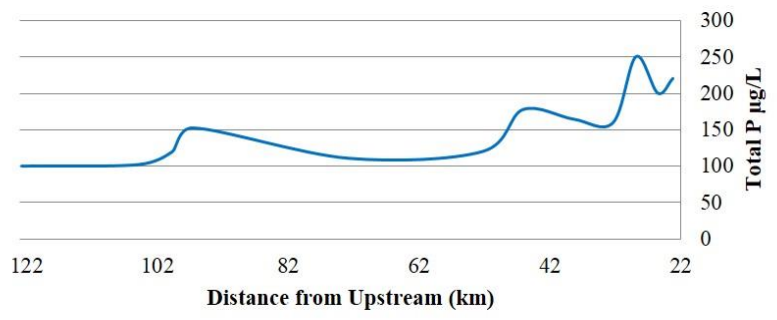

Fig. 4. Quality of total $\mathrm{P}$ in Cisadane river.

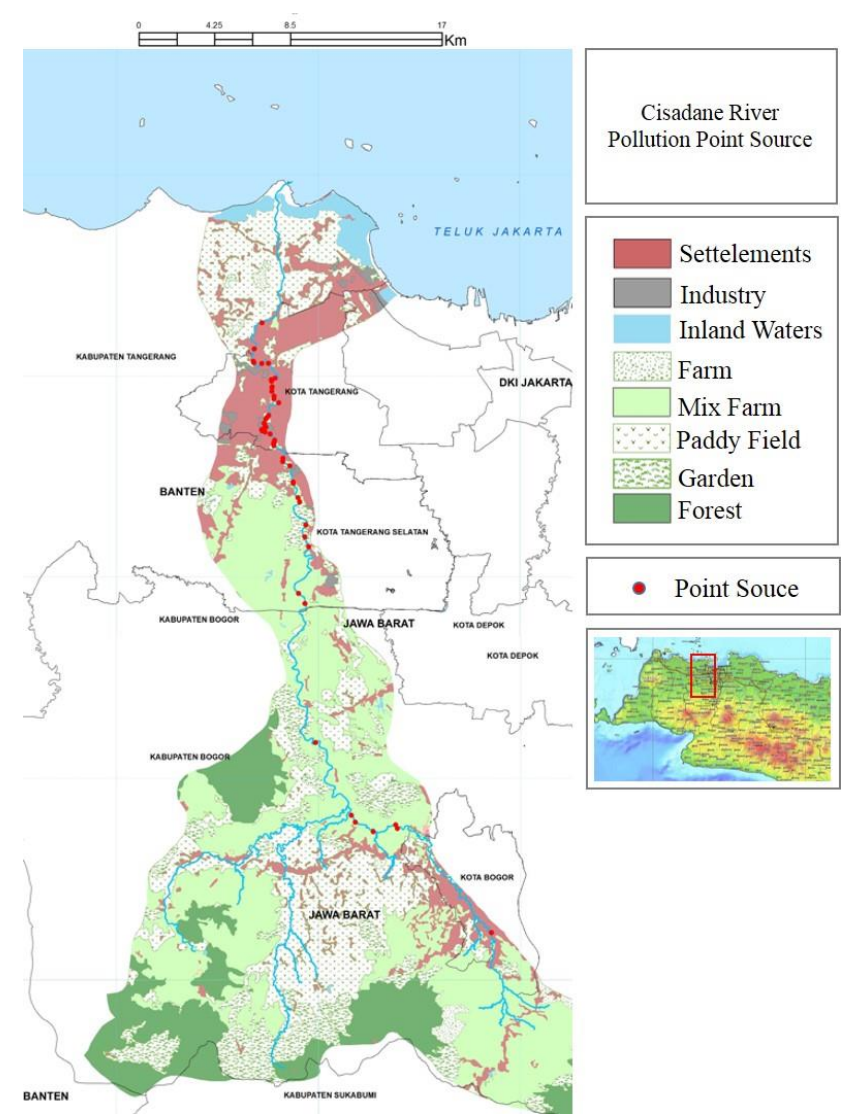

Fig. 5. Pollutant point source in Cisadane river. 
Meanwhile, Fig. 4 indicates that Total $\mathrm{P}$ values in several observation points meet the Second Class Benchmark which is $200 \mu \mathrm{g} / \mathrm{L}$. However, in several points, especially those leading to the downstream region (Kabupaten Tangerang and Kota Tangerang), the Total $\mathrm{P}$ concentration is greater and exceeding the benchmark, which is could prove harmful.

\section{B. Sources of Pollutant at Cisadane River}

To understand more about the sources of pollutant at Cisadane River, the point source of pollutant are illustrated in the following figure.

As shown in Fig. 5 above, the highest density of the distribution of sources of pollutant in Cisadane Watershed is situated at the City of Tangerang segment. In comparison to Fig. 1 (land cover), then there is a correlation between the number of sources of pollutant and the amount of pollutant load especially for such parameters as BOD and Total P. Meanwhile, on such segments as Bogor Regency and Tangerang Regency, there were not many points of waste water discharge as land use in the surrounding areas mostly are dedicated for garden, rice paddy field, and farm grounds. Therefore, more sources of pollutant in that segment are sources of pollutants which are non-point source pollutants scattered along Cisadane Watershed.

\section{Outcome of Pollutant Calculation Using QUAL2Kw Method in Cisadane River}

On the modelling of pollutant load, all data of pollutant load have been input to QUAL2Kw application to acquire pollutant load on each segment of the river. Sources of pollutant consist of domestic and industrial wastes. Calculation of industrial wastes are based on discharge data and quality of industrial waste which discharge their effluent wastes to Cisadane River.

Calculation of pollutant load along the Cisadane River uses QUAL2Kw application based on water quality data in the upstream region, water quality along the river, and sources of pollutant input in line with the average data of the monitoring years between 2009-2014. Those data were then processed to acquire pollutant load along the Cisadane River.

Parameters of pollutant load focused on this research are BOD, NO3, and Total P. BOD is oxygen amount needed by microorganism such as bacteria to decompose organic materials under aerobic conditions [4]. An indication that a waste contains organic substance is obtained by measuring the amount of oxygen necessary to decompose organic components into other components which are more stable [5].

\section{1) $B O D$}

Here is the BOD pollutant load along the Cisadane river:

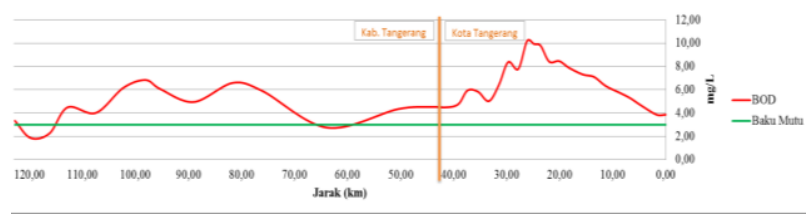

Fig. 6. BOD pollution loads along Cisadane river.

As shown in Fig. 6 above, it indicates that BOD values in almost all segments of Cisadane River do not meet the second class water quality benchmark. BOD values decrease between $\mathrm{Km} 80$ and $\mathrm{Km} 60$ points in which $\mathrm{Km} 60$ is located between Bogor Regency and Tangerang Regency borderline. Beyond Tangerang Regency, the BOD value increases and exceeds the benchmark. Therefore, BOD value at the upstream region of the Tangerang Municipality has exceeded the second class benchmark which ideally is at $3 \mathrm{mg} / \mathrm{L}$ but in reality it is $5.84 \mathrm{mg} / \mathrm{L}$.

\section{2) Nitrate}

The presence of nitrate in the water is one of the indicator that domestic waste has been transported into the water body [6]. This is especially true as discharge of domestic waste mostly contain urine, fecal matter, and oxidation of organic substances with a fairly high level of ammonia. The formation of ammonia has led to the increase of $\mathrm{pH}$ and temperature. Oxidation of ammonia into nitrate is known as nitrification and takes place under aerobic condition. Nitrate normally does not last long enough and a condition while oxidation process between ammonia and nitrate may take place in the river water.

Factors which affect the nitrification include among others: $\mathrm{pH}$, alkalinity, temperature, oxygen, salinity, and light. Formation of nitrate may lead to the decrease in $\mathrm{pH}$ value. Meanwhile, nitrate is a form of stable compound and its existence originate from the agricultural waste, fertilizers, human and animal excrements. The nitrite transformation into nitrate uses Nitrobacter sp bacteria. A condition where there are numerous forms of nitrogen may lead into uncontrollable growth of algae which may deplete the oxygen in the water. The load of Nitrate (NO3) pollutant is illustrated in Fig. 7.

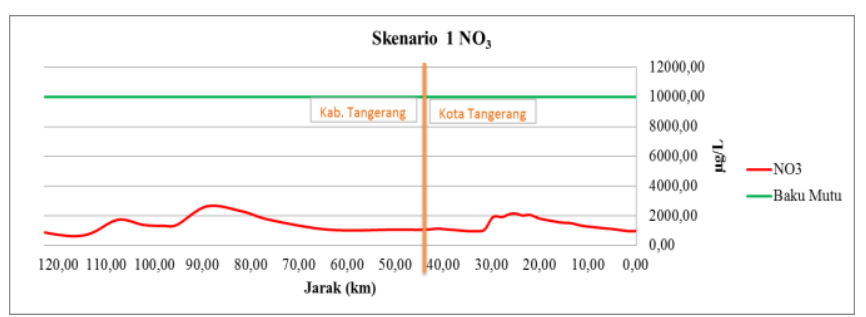

Fig. 7. $\mathrm{NO}_{3}$ pollution loads along Cisadane river.

Fig. 7 illustrates the NO3 values in all segments are still within the second class benchmark for NO3 that is $10 \mathrm{mg} / \mathrm{L}$ or $10,000 \mu \mathrm{g} / \mathrm{L}$.

\section{3) Phosphorus}

Phosphorus is present in the water through domestic waste water, urine, and through phosphorus components used in soaps and foams. Phosphorus presence indicate discharge from the domestic waste or settlement.

Most of the phosphorus on community waste water is present in the form of anorganic with orthophosphate such as PO43-, HPO42-, and H2PO4- [7], condensed phosphate such as pyrophosphates (P2O74-), metaphosphate (P3O93-), and polyphosphate (P4O136-, P3O105-). Orthophosphate is a form of phosphate which may be directly utilized by aquatic plants, while polyphosphate should undergo a hydrolisis to form an orthophosphate first before it can be utilized as the source of phosphorus [8]. The water which contains high level of phosphorus exceeding the normal requirements of water organism, may lead to a euthropication.

Level of phosphorus content permissible for drinking 
water purposes is $0.2 \mathrm{mg} /$ Liter in the form of phosphate (PO4). Meanwhile level of phosphorus in a natural water ranges between $0.005-0.02 \mathrm{mg} / \mathrm{L}$ in the form of PO4 [9]. The amount of Phosphorus pollutant load is presented in the following graph:

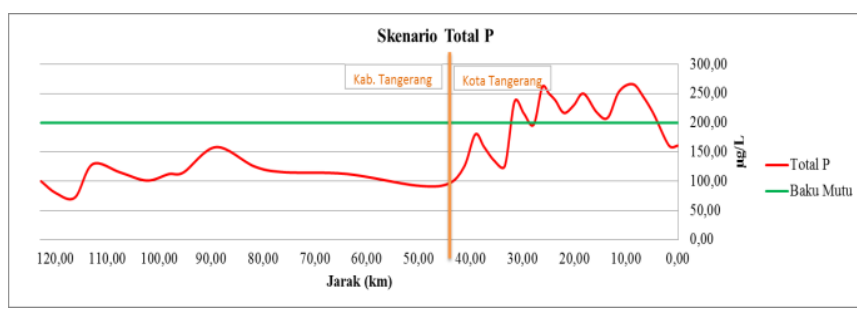

Fig. 8. $\mathrm{PO}_{4}$ pollution loads along Cisadane river.

Furthermore, As shown in Fig. 8 above indicates that Total $\mathrm{P}$ values consistently meet the second class benchmark starting from the upstream region at $\mathrm{km} 32$ point which is the borderline between Tangerang Regency and Tangerang Municipality. Meanwhile starting from $\mathrm{km} 32$ point down to $\mathrm{km} 2$ the Total P values exceed the second class benchmark and once again restore the values back to meeting the benchmark at $\mathrm{km} 0$ point in downstream area of Cisadane River.

\section{Outcome of Load Calculation Using QUAL2Kw Method in Cisadane River}

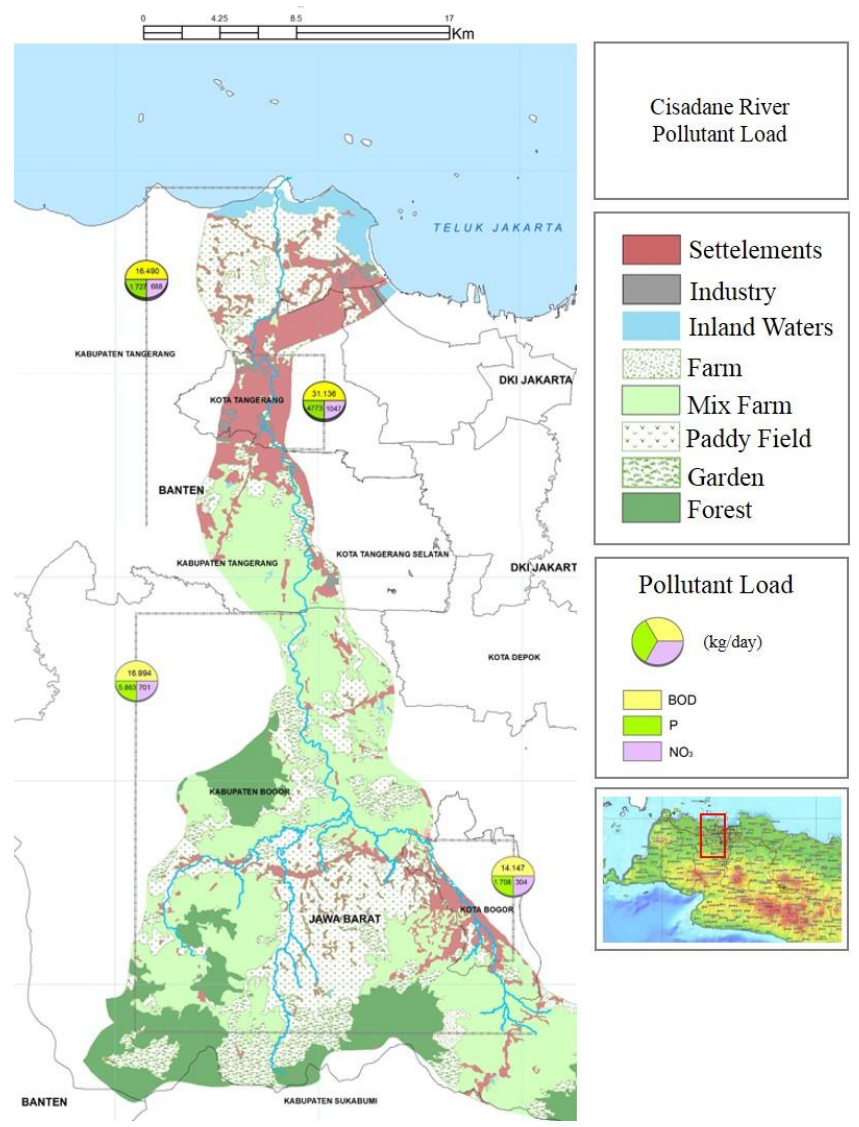

Fig. 9. Cisadane river pollutant load.

As shown above, Fig. 9 illustrates the pollutant load along the Cisadane River with the upstream borderline starting at Muara Jaya Village in Bogor Regency, down to Teluk Naga Village in Tangerang Regency. Based on the map illustration above, it is known that the greatest BDO and Total $\mathrm{P}$ pollutant loads are in Tangerang Municipality segment.
Based on the waste water inventory, it is known that the waste water of Tangerang Municipality segment is predominantly domestic waste originating from the surrounding community. It is known that the origin of BOD and Total $\mathrm{P}$ is the domestic waste water, thus causing the BOD and Total $\mathrm{P}$ pollutant loads at the Tangerang Municipality segment to be the greatest. However, the greatest level of $\mathrm{NO} 3$ pollutant load along the Cisadane River is at the Bogor Regency segment. NO3 is a form of stable compound in which the origin of its presence is from the agricultural discharge, fertilizers, human and animal excrements. Based on Fig. 1 on the land use surrounding the Cisadane River, it is apparent that the land use in Bogor Regency, especially in the upstream region of Cisadane River, mostly are rice paddy fields, plantation, and farmland. These are the leading causes on the degree of $\mathrm{NO} 3$ pollutant load in Bogor Regency segment.

TABLE I: TOTAL P POLLUTANT LOAD ON REGIONAL BASIS

\begin{tabular}{|c|c|}
\hline \multirow{2}{*}{ Municipality/Regency } & Total P \\
\cline { 2 - 2 } Bogor Regency & (kg/day) \\
\hline Bogor Municipality & 701.05 \\
\hline $\begin{array}{c}\text { Tangerang Regency + South Tangerang } \\
\text { Municipality }\end{array}$ & 304,72 \\
\hline Tangerang Municipality & 688,47 \\
\hline Source: Analysis, 2016 & $1.047,35$ \\
\hline
\end{tabular}

As shown in Table I above, based on the calculation, the Total $\mathrm{P}$ pollutant load along the Cisadane River is 2,741.59 $\mathrm{kg} /$ day in which the pollutant load of Tangerang Municipality itself is $1,047.35 \mathrm{~kg} /$ day or equivalent to $38.20 \%$ from the overall Total $\mathrm{P}$ pollutant load in Cisadane River.

The territorial waters of Jakarta Bay are semi enclosed has received a heavy load of pollutants in the form of domestic waste, organic, industrial, heavy metals and oil spills are likely to increase over time until it is feared has exceeded its carrying capacity [10]. The flow of Cisadane river across several areas has brought a variety of pollutants chart. Therefore, it is necessary to understand the pollutant flow from Cisadane rivers that will be affecting the water quality for the people.

\section{CONCLUSION}

Cisadane River flows through 2 administrative regions of difference provinces, thus it is classified as inter-provincial river (the Regulation of the Government of the Republic of Indonesia No. 38 of 2011 on River) [11]. Based on the outcome of data processing using QUAL2Kw method [12], the BOD values of Cisadane River have exceeded the Second Class Benchmark.

Leadng waste water discharge in the Cisadane River are found in the middle course of the river, while the upstream and downstream regions based on the land use map are mostly utilized for rice paddy fields, farmland, and plantation. Therefore, it is necessary to reduce the pollutant load in each 
city and regency passed through by Cisadane River, not only regions with BOD values exceeding the benchmark. Hence, the BOD values in all segments will eventually meet the benchmark.

In this study, differences in modelling outcome as demonstrated may be caused by different types and number of pollutant sources both point source and non-point source input into the model. This is primarily due to lack of point source data in several municipalities/regencies thus the data do not adequately represent waste water discharge in such area.

Every municipality/regency is expected to update the data on the source of pollutant in each region based on the watershed hence enable detailed calculation on such regions.

\section{REFERENCES}

[1] Kelompok Kerja Air Minum dan Penyehatan Lingkungan, Sungai Cisadane Tercemar Bakteri E. Coli. Jurnal Nasional, 2011, Menteng, Jakarta.

[2] R. Siahaan, A. Indrawan, D. Soedharma, and L. B. Prasetyo, Kualitas Air Sungai Cisadane, Jawa Barat-Banten, Bogor: IPB, 2011.

[3] S. C. Chapra et al., "QUAL2K: A modelling framework for simulating river and stream water quality (beta version): Documentation and users manual," Civil and Environmental Engineering Dept., Tufts University, 2003.

[4] D. Arief, "Pengukuran salinitas air laut dan peranannya dalam ilmu kelautan, Oseana," vol. IX, pp. 3-10, 1984.

[5] Metcalf and I. Eddy, Wastewater Engineering Treatment and Reuse, McGraw-Hill Companies, Inc., 2003.

[6] Sastrawijaya, Perencanaan Lingkungan, Penerbit PT Rinika Cipta, Cetakan kedua, Jakarta, 2000.

[7] Sugiharto, Dasar-Dasar Pengelolaan Air Limbah, Salemba, Jakarta, Indonesia: UI-Press, 1987.

[8] N. Clair and P. L. Sawyer, Chemistry for Environmental Engineering and Science, Mc Graw Hill, 1994.

[9] UNESCO/WHO/UNEP, University Press, Cambridge, 1992

[10] I. Suhendar and H. D. Sachoemar, "Kondisi pencemaran lingkungan Perairan di Teluk Jakarta," JAI, vol. 3, no. 1, 2007.

[11] Asdep Urusan Data dan Informasi KLH, "Daya Tampung Beban Pencemaran Cisadane Tahun 2008," Jakarta: Kementerian Negara Lingkungan Hidup, 2008.

[12] D. R. D. Marganingrum, "Diferensiasi Sumber Pencemar Sungai Menggunakan Pendekatan Metode Indeks Pencemaran (IP) (Studi Kasus: Hulu DAS Citarum)," Riset Geologi dan Pertambangan LIPI, 2013.

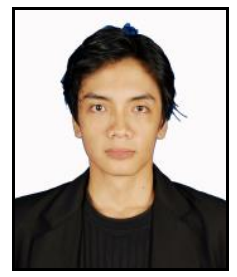

Adipati Rahmat Gumelar was born in Jakarta, May $8^{\text {th }}$ 1980. He is a master in urban studies from Universitas Indonesia, graduated in 2011.

$\mathrm{He}$ is currently active as a lecturer in Universitas Indonesia, Jakarta, Indonesia, teaching urban studies in the postgraduate program. He also works as a marine expert in directorate of small islands in Ministry of Fisheries and Marine Affairs. He also has six published articles, with two of them indexed Internationally: Smart coastal city: Sea pollution awareness for people in Surabaya Waterfront City (Surabaya, Indonesia, Elsevier, 2016) and simulated pollution dispersion at the coastal area, a case study in cirebon regency (Pune, India, IM-International, 2016). He's currently doing research in Waterfront Cities, Urban Studies, and Fisheries and Marine Spatial Planning.

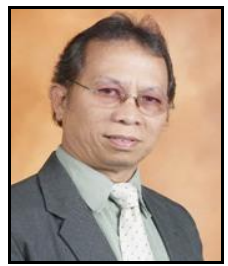

Abimanyu Takdir Alamsya is a lecturer of the Department of Architecture Faculty of Enginering, University of Indonesia, He was honored a professor in 2009, specializes in coastal architecture. He S1 graduated in architecture, Faculty Engineering University of Indonesia (FTUI) in 1975 and had opportunity to study Diploma in Development Planning (Dip.DP), Development Planning Unit, School for Environmental Studies, University College London, United Kingdom. He earned his Master of Science (in major - Regional and Rural Development), Bogor Agriculture Institute (IPB), Bogor, Indonesia. And then, he earned his doctorate degree in faculty of Environmental Science UI, in 2006 .

He has written and published over one hundred scientific articles from 1975 to 2011. His newest publication entitled A long way to improve community resilience inan archipelagic country which he presented in the Symposium Program From Post-Disaster Reconstruction To the Creation of Resilient Societies in December 2011 at Keio University, Tokyo.

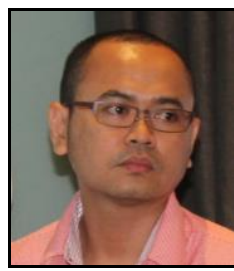

Ida Bagus Hendra Gupta was born in Denpasar, Bali. He is currently working at the Ministry of National Development Planning (BAPPENAS). He is also active in nitoring and evaluation specialist. He is currently taking a master programme at University of Indonesia since 2015 in urban studies. He has interest in social aspect in coastal development. And he recently published a paper titled "Coastal community resilience: construct of vulnerability and resilience of Kampung Teluk Naga" on the asia-pacific forum for research in social sciences and humanities conference.

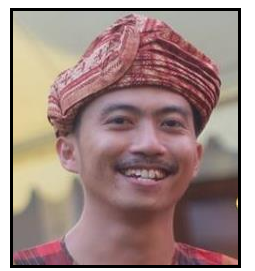

Darul Syahdanul was born in Makassar. He is currently working at Turuntangan, a civil society organization that actives on education field. He is currently taking a master programme at University of Indonesia since 2015 in Urban Studies. He has interest in coastal environment issues and social aspects. And he recently published a paper titled "Coastal community resilience: The social

transformation of teluknaga regency society along the Cisadane river watershed" on the asia-pacific forum for research in social sciences and humanities conference.

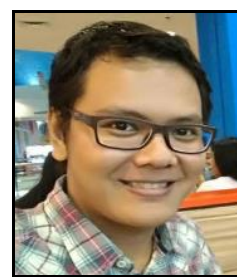

Daniel Mambo Tampi was born in Manado. He is currently taking a master programme at University of Indonesia since 2016 in Urban Studies. He has interest in social aspects of environment issues. 